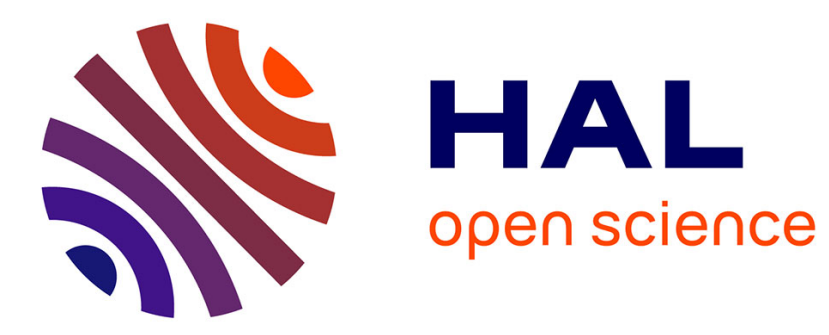

\title{
Holocene glacier culminations in the Western Alps and their hemispheric relevance
}

Irene Schimmelpfennig, J.M. Schaefer, N. Akçar, S. Ivy-Ochs, R. C. Finkel, C. Schlüchter

\section{- To cite this version:}

Irene Schimmelpfennig, J.M. Schaefer, N. Akçar, S. Ivy-Ochs, R. C. Finkel, et al.. Holocene glacier culminations in the Western Alps and their hemispheric relevance. Geology, 2012, 40 (10), pp.891-894. 10.1130/G33169.1 . hal-01680367

\section{HAL Id: hal-01680367 https://hal.science/hal-01680367}

Submitted on 1 May 2019

HAL is a multi-disciplinary open access archive for the deposit and dissemination of scientific research documents, whether they are published or not. The documents may come from teaching and research institutions in France or abroad, or from public or private research centers.
L'archive ouverte pluridisciplinaire HAL, est destinée au dépôt et à la diffusion de documents scientifiques de niveau recherche, publiés ou non, émanant des établissements d'enseignement et de recherche français ou étrangers, des laboratoires publics ou privés. 
Publisher: GSA

Journal: GEOL: Geology

Article ID: G33169

\section{Holocene glacier culminations in the Western Alps and their}

\section{2 hemispheric relevance}

3 I. Schimmelpfennig ${ }^{1}$, J.M. Schaefer ${ }^{1,2}$, N. Akçar ${ }^{3}$, S. Ivy-Ochs ${ }^{4}$, R.C. Finkel ${ }^{5}$, and C.

4 Schlüchter ${ }^{3}$

$5{ }^{1}$ Lamont-Doherty Earth Observatory, Palisades, NY, USA

$6{ }^{2}$ Department of Earth and Environmental Sciences, Columbia University, New York, NY, USA

$7{ }^{3}$ Institute of Geological Sciences, University of Bern, Switzerland

$8{ }^{4}$ Insitut für Teilchenphysik, Eidgenössische Technische Hochschule Zürich, Switzerland

$9{ }^{5}$ Earth and Planetary Science Department, University of California-Berkeley, CA, USA

10 ABSTRACT

11 The natural variability of Holocene climate defines the baseline to assess ongoing climate

12 change. Greenland ice-core records indicate warming superimposed by abrupt climate

13 oscillations in the early Holocene, followed by a general cooling trend throughout the mid- and

14 late Holocene that culminated during the Little Ice Age (LIA). Tropical precipitation changes

15 correlate with these patterns throughout the Holocene.

16 Here we use mountain glaciers in the Alps to reconstruct the regional Holocene climate

17 evolution and to test for a link between mid-latitude, North Atlantic and tropical climate. Our

18 precise ${ }^{10} \mathrm{Be}$ chronology from Tsidjiore Nouve Glacier, western Swiss Alps, indicates a glacier

19 culmination during the earliest Holocene $\sim 11.4$ k.y. ago, likely related to the Preboreal

20 Oscillation. Based on our data, no Holocene glacier advance of similar amplitude occurred until

$21 \sim 3.8$ k.y. ago, when the glacier reached LIA limits. ${ }^{10}$ Be ages between 500 and $170 \mathrm{yr}$

22 correspond to the LIA, while the youngest ${ }^{10} \mathrm{Be}$ ages overlap with the historically recorded post- 
Publisher: GSA

Journal: GEOL: Geology

Article ID: G33169

23 LIA glacier positions. Integrating our data with existing records, we propose a hemispheric

24 climate link between the Alps, North Atlantic temperature and tropical precipitation patterns for

25 the Holocene, supporting the concept of a pervasive climate driver. These findings from northern

26 mid-latitudes are consistent with the hypothesis formulated for the tropics that the earth's thermal

27 equator, responding to North Atlantic temperature changes, might have migrated southward

28 throughout the Holocene, reaching the southern turning point towards the end of the LIA.

29 INTRODUCTION

While there is increasing evidence that the climate during the current warm period, the

31 Holocene, has been less stable than originally thought (e.g., Haug et al., 2001), robust terrestrial

32 data quantifying Holocene climate changes remain sparse mostly due to their moderate

33 amplitude compared to the dramatic climate fluctuations during ice-ages. The Greenland

34 temperature record indicates rapid warming after the Younger Dryas (YD, $\sim 12,900-11,700$ years

35 ago), interrupted by early Holocene abrupt cold events such as the Preboreal Oscillation (PBO;

36 Rasmussen et al., 2007). Warm early Holocene conditions in the North Atlantic area are

37 followed by a long-term cooling (Cuffey and Clow, 1997), culminating in the Little Ice Age

38 (LIA, 1300-1850 common era, CE, e.g. Holzhauser et al., 2005). Hydrological changes in the

39 tropics correlate with long- and short-term climate events in the North Atlantic (Haug et al.,

40 2001; Sachs et al., 2009), implying shifts in the Intertropical Convergence Zone (ITCZ) as a

41 result of the thermal equator adjusting to northern temperature changes. If this scenario is

42 correct, the mid-latitudes should have responded to polar cold and warm spells, but evidence

43 remains controversial.

44 Here we use glacier fluctuations in the Western Alps to reconstruct regional Holocene

45 climate patterns and to test the link between polar climate changes and mid-latitude mountain 
Publisher: GSA

Journal: GEOL: Geology

Article ID: G33169

46 glaciers, which are highly sensitive to regional climate changes and in particular, to summer

47 temperature variations (Oerlemans, 2005). We produced a detailed moraine map and a precise

$48{ }^{10} \mathrm{Be}$ chronology for one of the best resolved Holocene lateral moraine sequences in the Alps

49 (Fig. 1); it was deposited by the Tsidjiore Nouve Glacier in the Valais, Switzerland, one of the

50 most climate sensitive glaciers in the Swiss Alps (Röthlisberger, 1976). The overall goal of this

51 study is to test for glacier fluctuations related to the early Holocene abrupt climate changes and

52 to add constraints of climate's evolution during the mid- and late Holocene, including the LIA

53 period. In the Alps, Holocene moraine chronologies are scarce (Joerin et al., 2006), as the LIA

54 advances wiped out the older moraines in most places (Röthlisberger and Schneebeli, 1979). A

55 few pioneering surface exposure dating studies from the Swiss and Austrian Alps (Ivy-Ochs et

56 al., 2009; Schindelwig et al., 2011) report glacier advances exceeding the LIA position during

57 the early Holocene, and correlate those advances to North Atlantic cold pulses.

58 GEOMORPHIC SETTING

59 The well-preserved sequence of Holocene lateral moraine ridges at Tsidjiore Nouve

60 Glacier (Fig. 1) is composed of i) an outermost pre-L/A moraine: an up to $20 \mathrm{~m}$ high and $1 \mathrm{~km}$

61 long well-defined moraine ridge. At least five recessional sub-ridges, less than $1 \mathrm{~m}$ high, line its

62 ice-proximal flank. Large boulders are embedded on all ridges; ii) a 'LIA' composite moraine:

63 An up to $60 \mathrm{~m}$ high and $3 \mathrm{~km}$ long moraine wall, formed by at least five sub-ridges with few

64 boulders. Such massive composite moraines fringing the non-vegetated glacier forefield are

65 typically referred to as 'LIA' moraines in the Alps (Röthlisberger and Schneebeli, 1979); iii) an

66 outer and an inner post-LIA moraine inside of the 'LIA' composite moraine with several

67 embedded boulders. These two moraines are assigned to $1920 \mathrm{CE}$ and $1991 \mathrm{CE}$, respectively 
Publisher: GSA

Journal: GEOL: Geology

Article ID: G33169

68 (Abbühl et al., 2009; Fig. 1), based on direct measurements of the glacier length changes of

69 numerous glaciers in this region (Glaciological reports, 1881-2009, Fig. DR1).

METHODS

We collected 29 surface samples from large boulders protruding $>0.80 \mathrm{~m}$ from the lateral moraine ridges of Tsidjiore Nouve Glacier (Figs. 1 and DR2). All samples were processed for

${ }^{10} \mathrm{Be}$ measurements at the Lamont-Doherty Earth Observatory Cosmogenic Nuclide Laboratory

74 (method in Schaefer et al., 2009; http://www.ldeo.columbia.edu/cosmo/). ${ }^{10} \mathrm{Be} /{ }^{9} \mathrm{Be}$ ratios were

75 measured at the Center for Accelerator Mass Spectrometry, Lawrence Livermore National

76 Laboratory. To calculate the surface exposure ages, we used the ${ }^{10}$ Be production rate calibrated

77 in northeastern North America (Balco et al., 2009), whose value is confirmed by several recent

78 calibration experiments elsewhere in the Northern Hemisphere (e.g., Fenton et al., 2011, Briner

79 et al., 2012). ${ }^{10}$ Be ages are reported in years before $2010 \mathrm{CE}$.

80 RESULTS

81 The ${ }^{10}$ Be chronology at Tsidjiore Nouve is shown in Figure 1 and Table DR1. Ages from

82 the pre-LIA moraine crest $(\mathrm{n}=10)$ range from 10.9 to $11.9 \mathrm{k} . \mathrm{y}$. with an arithmetic mean and

83 standard deviation of $11.4 \pm 0.4$ k.y. $( \pm 0.7$ k.y. including the production rate uncertainty for

84 comparison with other climate proxies, shown in italic below; Fig. 2). Ages from the recessional

85 ridges of the pre-LIA moraine $(\mathrm{n}=7)$ are between 10.9 and $11.5 \mathrm{k} . \mathrm{y}$. , and the arithmetic mean is

$8611.2 \pm 0.2$ k.y. $( \pm 0.6$ k.y.; Fig. 2). The error-weighted mean ages, $11.44 \pm 0.06$ k.y. for the crest

87 and $11.25 \pm 0.08$ k.y. for the recessional ridges are consistent with the stratigraphy.

88 The ages from the 'LIA' composite moraine can be divided into two groups. (i) Three

89 ages in the central part of the outmost crest are $3790 \pm 200(\mathrm{ARO}-12), 3320 \pm 170(\mathrm{ARO}-13)$ and

$903200 \pm 180$ (ARO-11) years (Fig. 1). The oldest boulder protrudes from the ice-distal side of this 
Publisher: GSA

Journal: GEOL: Geology

Article ID: G33169

91 ridge, and the two younger boulders from the ice-proximal side (Fig. DR3), yielding an

92 arithmetic mean of $3260 \pm 180$ years. (ii) We obtain ages of $480 \pm 30$ (ARO-10) and $180 \pm 10$

93 years (ARO-9) for boulders on an inner crest; ARO-9 is from a more ice-proximal area than

94 boulder ARO-10 (Fig. DR3). On the lowest-elevation segment of the composite moraine, in a

95 stratigraphically similar position as ARO-10, sample ARO-23 yields an age of $580 \pm 30$ years.

96 The five samples from the outer post-LIA moraine yield ages of $170 \pm 10$ years (ARO-

97 66), $150 \pm 10$ years (ARO-67), $150 \pm 10$ (ARO-63), $110 \pm 10$ years (ARO-65) and $100 \pm 10$

98 years (ARO-64). One sample from the inner post-LIA moraine yields an age of $120 \pm 10$ years

99 (ARO-62).

100 DISCUSSION

101 The glacier chronology at Tsidjiore Nouve yields constraints for five periods of Holocene 102 glacier fluctuations (Fig. 3A), which we compare to other terrestrial records in the northern mid-

103 latitudes, and to North Atlantic temperature and tropical precipitation records (Fig. 3):

104 (i) Earliest Holocene: The mean age of the pre-LIA moraine crest of $\sim 11.4$ k.y. indicates that the

105 Tsidjiore Nouve Glacier was close to its LIA-limits at or shortly after the YD/earliest

106 Holocene transition. The mean age of the recessional ridges is slightly younger ( 11.2 k.y.)

107 indicating that the glacier might have retreated slowly from the crest over a few centuries.

108 The age range for this moraine overlaps with both the late YD and the PBO (Fig. 3A), a brief

109 cold-spell identified in the Greenland ice cores, peaking 11.40 k.y. ago and terminating 11.27

110 k.y. ago (Rasmussen et al., 2007; Kobashi et al., 2008; Fig. 3G). Chronologically, two

111 scenarios are possible: Either the pre-LIA moraine corresponds to a late YD position of the

112 glacier, followed by a slow oscillatory retreat during the PBO marked by the recessional

113 ridges; or the pre-LIA moraine was deposited during the $\mathrm{PBO}$, interrupting the glacier retreat 
Publisher: GSA

Journal: GEOL: Geology

Article ID: G33169

114 from the more extensive late glacial position. Traditionally, the YD has been related to the

115 'Egesen Stadial' in the Alps (Ivy-Ochs et al., 2009, and references herein) with Egesen

116 snowlines in the region of Tsidjiore Nouve Glacier (Valais) being $200 \mathrm{~m}$ below the LIA

117 maximum (Maisch, 1987), far downstream of the pre-LIA moraine. Adopting this scenario

118 here, it appears more likely that the pre-LIA moraine is related to the PBO. Independent

119 evidence in the Alps further supports the PBO signature (Fig. 3): Burga (1987) reports an

120 increase in non-arboreal pollen during the earliest Holocene in a peat bog at Palü Glacier

121 (Eastern Swiss Alps) and infers a glacier advance beyond its LIA extent ("Palü Oscillation").

$122 \quad \delta^{18} \mathrm{O}$ changes in Swiss lake sediments showing a strong similarity with the Greenland $\delta^{18} \mathrm{O}$

123 record reveal a distinct, 'PBO-type' signal shortly after the YD termination (Schwander et

124 al., 2000, Fig. 3F). Further evidence for the PBO in European and North American lacustrine

125 and glacial records (e.g., Björck et al., 1997; Hu et al., 2006) suggest a wide geographic

126 footprint of this short cold spell.

127 (ii) Early and mid-Holocene: It is characteristic for the Alps that no moraines are preserved

128 during the early and mid-Holocene, suggesting that glaciers were smaller during this period

129 than during the LIA (Holzhauser et al., 2005). In Greenland, a warming of $4 \pm 1.5^{\circ} \mathrm{C}$ within

$130 \sim 14$ years is recorded at the end of the PBO (Kobashi et al., 2008). The manifestation of this

131 abrupt warming might have driven glaciers in the Alps far inside their LIA configuration,

132 where they remained during the entire mid-Holocene. Warm early to mid-Holocene climate

133 is also supported by recent studies from the European Alps: Mont Miné Glacier, a

134 neighboring glacier of Tsidjiore Nouve, was smaller than today 9 k.y. ago, before a short-

135 lived, minor advance 8.2 k.y. ago killed many trees growing up-valley of today’s glacier

136 terminus (Nicolussi and Schlüchter, 2012; Fig. 3C); Swiss glaciers were smaller than today 
Publisher: GSA

Journal: GEOL: Geology

Article ID: G33169

137 during the early and mid-Holocene, based on sub-fossil wood and peat records (Joerin et al.,

138 2006, Fig. 3D); a speleothem record implies that the Upper Grindelwald Glacier (Swiss Alps)

139 was in a quasi-continuously retracted position until 5.8 k.y., followed by a period of larger

140 glaciers (Luetscher et al., 2011, Fig. 3E). Re-advances of glaciers in the Alps during the

141 second half of the Holocene agree with the general cooling trend in Greenland (Cuffey and

142 Clow, 1997; Fig. 3H) and correlate with a precipitation decrease in the tropics (Haug et al.,

143 2001; Fig. 3I), both beginning after the thermal maximum $\sim 7.5$ k.y. ago and culminating in

144 the LIA.

145 (iii) Late Holocene: The three boulder ages from the oldest segment of the 'LIA' composite

146 moraine provide less robust age constraints, but indicate that the glacier was similar to LIA

147 size $3.8-3.2$ k.y. ago. We cannot entirely exclude the possibility of ${ }^{10} \mathrm{Be}$ accumulation prior

148 to final boulder deposition. However, several arguments support the view that these three

149 ages represent the formation of this moraine segment. First, the chronology agrees with the

150 stratigraphic order. Second, the ${ }^{14} \mathrm{C}$-dating of a larch log found in the basal till of the

151 proglacial streambed yielded an age of 3440-2770 cal yr B.P. (Table DR2), consistent with

152 the two younger ${ }^{10} \mathrm{Be}$ ages, implying an advance of the glacier at that time (Röthlisberger,

153 1976). This scenario is further supported by ${ }^{14} \mathrm{C}$ dates on two fossil soils that formed on this

154 moraine 1510-1080 cal yr B.P. (lower horizon) and 1180-800 cal yr B.P. (upper horizon;

155 Röthlisberger, 1976, Table DR2). The ${ }^{14} \mathrm{C}$ dates assign a conservative minimum age to this

156 moraine, supporting the pre-LIA ${ }^{10} \mathrm{Be}$ ages. Interestingly, both soil-dates fall within the

157 Medieval Warm Period (MWP; Fig. 3B). Other studies in the European Alps support the

158 onset of substantial glacier re-advances to 'LIA extent' $\sim 3.8$ k.y. ago. The speleothem record

159 at Upper Grindelwald Glacier implies glacier advances close to its Holocene peak extent 
Publisher: GSA

Journal: GEOL: Geology

Article ID: G33169

160 from 3.8 k.y. ago onward (Luetscher et al., 2011, Fig. 3E). Patzelt and Bortenschlager (1973)

161 define the "Löbben Oscillation" 4.0-3.0 cal kyr ago based on ${ }^{14} \mathrm{C}$-dates of the advance of

162 two glaciers and climatic deterioration in a pollen record in Austria. Glacier culminations at

163 that time are also documented in other regions of the Northern Hemisphere. According to

164 Menounos et al. (2009) and references therein, glaciers in western Canada reached 'LIA-

165 extent' by 3.5 k.y. ago, based on ${ }^{14}$ C-dates from proglacial detrital and in situ wood. In

166 southeastern Alaska, ${ }^{14} \mathrm{C}$-dates of a tree-ring series indicate a glacial expansion $\sim 3.4-3.0$ k.y.

167 ago (Wiles et al., 2011). In the tropics, the period between $\sim 3.8$ and 2.8 k.y. ago is marked by

168 centennial-scale, large-amplitude variations in precipitation, including several precipitation

169 minima similar to those during the LIA (Haug et al., 2001; Fig. 3I).

170 (iv) Little Ice Age: Lasting from about 1300-1850 CE, the LIA in the Swiss Alps showed three

171 maxima, c. 1350, 1650 and $1850 \mathrm{CE}$ (Holzhauser et al., 2005). The three younger ages on the

172 inner sub-ridge of the composite moraine correspond to the years $1430 \pm 32,1534 \pm 28,1829$

$173 \pm 11 \mathrm{CE}$, all within the LIA period. A drawing of Tsidjiore Nouve Glacier from $1836 \mathrm{CE}$

174 (Fig. DR4) testifies the advanced position of the glacier terminus to be more than $1 \mathrm{~km}$

175 downvalley of its modern position, and is in general agreement with the boulder age

176 corresponding to $1829 \pm 11 \mathrm{CE}(\mathrm{ARO}-9)$.

177 (v) Little Ice Age Termination: Our six post-LIA boulder ages correspond to the years between

$178 \quad 1840 \pm 13$ and $1906 \pm 11 \mathrm{CE}$, broadly overlapping with the historic record (Glaciological

179 reports, 1881-2009; Fig. DR1). Offsets of $\sim 15$ to 100 years between the ${ }^{10} \mathrm{Be}$ ages and the

180 historically recorded deposition years of the post-LIA moraines (Fig. 1) are probably due to a

181 small ${ }^{10} \mathrm{Be}$ signal $\left(\sim 300-2000\right.$ atoms $\left.{ }^{10} \mathrm{Be} \mathrm{g}^{-1}\right)$ inherited from previous exposure. This result

182 underlines the potential to resolve (sub-)centennial climate events during the last millennium 
Publisher: GSA

Journal: GEOL: Geology

Article ID: G33169

183 with ${ }^{10} \mathrm{Be}$ dating of moraines, previously only reported from New Zealand (Schaefer et al., 184 2009) and Peru (Licciardi et al., 2009).

185 CONCLUSION

186 We make the case that Holocene glacier fluctuations in the western Alps (i.e., mid-

187 latitude temperatures) are related to North Atlantic temperature changes and the tropical

188 hydrological cycle, confirming a hemispheric climate link. Our observations thus reinforce the

189 concept of a common hemispheric driving mechanism and support the scenario that the earth's

190 thermal equator and the connected westerly winds have shifted south over several millennia

191 during the Holocene in response to North Atlantic temperature changes, reaching its

192 southernmost position during the LIA (Sachs et al., 2009).

193 ACKNOWLEDGMENTS

We thank R. Schwartz, J. Hanley and J. Frisch for help with sample preparation, A.

195 Putnam for assistance during figure preparation, and the staff of LLNL-CAMS for the

196 excellent measurements. We acknowledge support by the CRONUS-Earth project (NSF

197 Grant EAR-0345835), by the International Balzan Foundation and the German Academic

198 Exchange Service (DAAD). This is Lamont-Doherty Earth Observatory publication 7540.

199 Comments from Jason Briner and two anonymous reviewers greatly improved this

200 manuscript.

201 REFERENCES CITED

202 Abbühl, L., Akçar, N., Strasky, S., Graf, A., Ivy-Ochs, S., and Schlüchter, C., 2009, A zero-

203 exposure time experiment on an erratic boulder: Evaluating the problem of pre-exposure in

204 Surface Exposure Dating, Eiszeitalter und Gegenwart: Quaternary Sciences Journal, v. 58, 205 p. 1-11. 
Publisher: GSA

Journal: GEOL: Geology

Article ID: G33169

206 Balco, G., Briner, J., Finkel, R.C., Rayburn, J.A., Ridge, J.C., and Schaefer, J.M., 2009, Regional

207 beryllium-10 production rate calibration for late-glacial northeastern North America:

208 Quaternary Geochronology, v. 4, p. 93-107, doi:10.1016/j.quageo.2008.09.001.

209 Björck, S., Rundgren, M., Ingólfsson, Ó., and Funder, S., 1997, The Preboreal oscillation around 210 the Nordic Seas: Terrestrial and lacustrine responses: Journal of Quaternary Science, v. 12,

212 Briner, J.P., Young, N.E., Goehring, B.M., and Schaefer, J.M., 2012, Constraining Holocene

$213{ }^{10}$ Be production rates in Greenland, Journal of Quaternary Science, v. 27, p. 2-6, doi:

$214 \quad 10.1002 /$ jqs.1562.

215 Burga, C.A., 1987, Gletscher- und Vegetationsgeschichte der südrätischen Alpen seit der

216 Späteiszeit (Puschlav, Livigno, Bormiese): Denkschriften der Schweizerischen

217 Naturforschenden Gesellschaft, v. 101, 162 p.

218 Cuffey, K., and Clow, G., 1997, Temperature, accumulation, and ice sheet elevation in central

219 Greenland through the last deglacial transition: Journal of Geophysical Research, v. 102,

220 p. $26383-26396$, doi:10.1029/96JC03981.

221 Fenton, C.R., Hermanns, R.L., Blikra, L.H., Kubik, P.W., Bryant, C., Niedermann, S., Meixner, 222 A., and Goethals, M.M., 2011, Regional ${ }^{10}$ Be production rate calibration for the past $12 \mathrm{ka}$ deduced from the radiocarbon-dated Grøtlandsura and Russenes rock avalanches at $69^{\circ} \mathrm{N}$,

225 Glaciological reports, 1881-2009, “The Swiss Glaciers”, Yearbooks of the Cryospheric

226 Commission of the Swiss Academy of Sciences (SCNAT) published since 1964 by the

227 Laboratory of Hydraulics, Hydrology and Glaciology (VAW) of ETH Zürich. No 1-126.

$228 \quad$ (http://glaciology.ethz.ch/swiss-glaciers/) 
Publisher: GSA

Journal: GEOL: Geology

Article ID: G33169

229 Haug, G.H., Hughen, K.A., Sigman, D.M., Peterson, L.C., and Röhl, U., 2001, Southward

230 migration of the Intertropical Convergence Zone through the Holocene: Science, v. 293,

231 p. 1304-1308, doi:10.1126/science. 1059725.

232 Holzhauser, H., Magny, M., and Zumbühl, H.J., 2005, Glacier and lake-level variations in west-

233 central Europe over the last 3500 years: The Holocene, v. 15, p. 789-801,

234 doi:10.1191/0959683605hl853ra.

235 Hu, F., Nelson, D., Clarke, G., Rühland, K., Huang, Y., Kaufman, D., and Smol, J., 2006, Abrupt

236 climatic events during the last glacial-interglacial transition in Alaska: Geophysical

237 Research Letters, v. 33, L18708, 5 p.

238 Ivy-Ochs, S., Kerschner, H., Maisch, M., Christl, M., Kubik, P.W., and Schluechter, C., 2009,

239 Latest Pleistocene and Holocene glacier variations in the European Alps: Quaternary

$240 \quad$ Science Reviews, v. 28, p. 2137-2149, doi:10.1016/j.quascirev.2009.03.009.

241 Joerin, U.E., Stocker, T.F., and Schlüchter, C., 2006, Multicentury glacier fluctuations in the

242 Swiss Alps during the Holocene: The Holocene, v. 16, p. 697-704,

243 doi:10.1191/0959683606hl964rp.

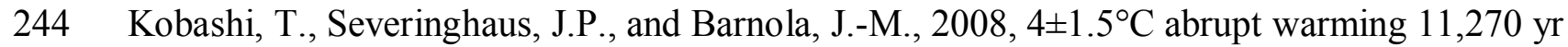

245 ago identified from trapped air in Greenland ice: Earth and Planetary Science Letters, v. 268,

246 p. 397-407, doi:10.1016/j.eps1.2008.01.032.

247 Licciardi, J.M., Schaefer, J.M., Taggart, J.R., and Lund, D.C., 2009, Holocene glacier

248 fluctuations in the Peruvian Andes indicate northern climate linkages. Science, v. 324, p.

$249 \quad$ 1677-1679, doi: 10.1126/science.1175010. 
Publisher: GSA

Journal: GEOL: Geology

Article ID: G33169

250 Luetscher, M., Hoffmann, D.L., Frisia, S., and Spötl, C., 2011, Holocene glacier history from

251 alpine speleothems, Milchbach cave, Switzerland: Earth and Planetary Science Letters,

252 v. 302 , p. $95-106$, doi:10.1016/j.epsl.2010.11.042.

253 Maisch, M., 1987, Zur Gletschergeschichte des alpinen Spätglazials: Analyse und Interpretation

254 von Schneegrenzdaten: Geographica Helvetica, v. 42, p. 63-71.

255 Menounos, B., Osborn, G., Clague, J.J., and Luckman, B.H., 2009, Latest Pleistocene and

256 Holocene glacier fluctuations in western Canada: Quaternary Science Reviews, v. 28,

257 p. 2049-2074, doi:10.1016/j.quascirev.2008.10.018.

258 Nicolussi, K., and Schlüchter, C., 2012, The 8.2 ka event - calendar dated glacier response in the 259 Alps: Geology (in press).

260 Oerlemans, J., 2005, Extracting a Climate Signal from 169 Glacier Records: Science, v. 308, 261 p. 675-677, doi:10.1126/science.1107046.

262 Patzelt, G., and Bortenschlager, S., 1973, Die postglazialen Gletscher- und Klimaschwankungen

263 in der Venedigergruppe (Hohe Tauern, Ostalpen), Zeitschrift für Geomorphologie N.F:

264 Supplementband, v. 16, p. 27-48.

265 Rasmussen, S.O., Vinther, B.M., Clausen, H.B., and Andersen, K.K., 2007, Early Holocene

266 climate oscillations recorded in three Greenland ice cores: Quaternary Science Reviews,

267 v. 26, p. 1907-1914, doi:10.1016/j.quascirev.2007.06.015.

268 Röthlisberger, F., 1976, Gletscher- und Klimaschwankungen im Raum Zermatt, Ferpècle und

269 Arolla: Die Alpen, v. 52, p. 59-152.

270 Röthlisberger, F., and Schneebeli, W., 1979, Genesis of lateral moraine complexes, demonstrated 271 by fossil soils and trunks: indicators of postglacial climatic fluctuations, in Schlüchter, C., 272 ed., Moraines and Varves: Rotterdam, A.A. Balkema, p. 387-419. 
Publisher: GSA

Journal: GEOL: Geology

Article ID: G33169

273 Sachs, J.P., Sachse, D., Smittenberg, R.H., Zhang, Z., Battisti, D.S., and Golubic, S., 2009,

274 Southward movement of the Pacific intertropical convergence zone AD 1400-1850: Nature

275 Geoscience, v. 2, p. 519-525, doi:10.1038/ngeo554.

276 Schaefer, J., Denton, G., Kaplan, M., Putnam, A., Finkel, R., Barrell, D., Andersen, B.,

277 Schwartz, R., Mackintosh, A., Chinn, T., and Schluechter, C., 2009, High-frequency

278 Holocene glacier fluctuations in New Zealand differ from the northern signature: Science,

$279 \quad$ v. 324 , p. $622-625$, doi: $10.1126 /$ science. 1169312.

280 Schindelwig, I., Akçar, N., Kubik, P.W., and Schlüchter, C., 2011, Lateglacial and early

281 Holocene dynamics of adjacent valley glaciers in the Western Swiss Alps: Journal of

282 Quaternary Science, doi:10.1002/jqs.1523.

283 Schwander, J., Eicher, U., and Ammann, B., 2000, Oxygen isotopes of lake marl at Gerzensee and Leysin (Switzerland), covering the Younger Dryas and two minor oscillations, and their correlation to the GRIP ice core: Palaeogeography, Palaeoclimatology, Palaeoecology, v. 159, p. 203-214, doi:10.1016/S0031-0182(00)00085-7.

Stuiver, M., Grootes, P.M., and Braziunas, T.F., 1995, The GISP2 $\delta^{18} \mathrm{O}$ climate record of the past 16,500 years and the role of the sun, ocean, and volcanoes: Quaternary Research, v. 44,

290 Wiles, G.C., Lawson, D.E., Lyon, E., Wiesenberg, N., and D’Arrigo, R.D., 2011, Tree-ring dates on two pre-Little Ice Age advances in Glacier Bay National Park and Preserve, Alaska,

293 FIGURES CAPTIONS

294 Figure 1. Map of the Holocene moraine sequence at Tsidjiore Nouve Glacier with ${ }^{10} \mathrm{Be}$ surface295 exposure ages (arithmetic means, $1 \sigma$ uncertainties and sample names). LIA $=$ Little Ice Age. The 
Publisher: GSA

Journal: GEOL: Geology

Article ID: G33169

296 inset shows the study area in red. Individual ages of the pre-LIA moraine are given with

297 analytical errors only; the boulder ages of the other moraines include the production rate

298 uncertainty. Yellow boxes show the moraine names as used in the main text, blue boxes show the

299 ages of historically recorded moraines (Abbühl et al., 2009). Estimates of four moraine

300 deposition ages based on ${ }^{14} \mathrm{C}$ dated fossil soils and logs (Röthlisberger, 1976, Fig. DR5D) are

301 given in dark green boxes, and the calibrated ${ }^{14} \mathrm{C}$ ages of two fossil soils are shown in light green

302 (Röthlisberger, 1976, Fig. DR5A,B). Legend: "Late Holocene" refers here to the period starting

3034 k.y. ago, excluding LIA and post-LIA. See Fig. DR3 for zoom-in of the 'Late Holocene/LIA'

304 complex.

305 Figure 2. Summed probability curves of ${ }^{10} \mathrm{Be}$ ages from the crest and the recessional ridges of the

306 pre-LIA moraine ridge. Individual ages in probability plots include propagation of analytical

307 errors. The yellow bands denote the arithmetic means (= Ar. mean) and the standard deviations

308 (=st.dv.). See Table DR3 for statistics.

309 Figure 3. Comparison of Holocene climate records in the European Alps (upper panel), in

310 Greenland (middle panel) and in the tropics (lower panel). Blue generally indicates colder (in the

311 tropics dryer) and red warmer (in tropics wetter) conditions. LIA = Little Ice Age; MWP =

312 Medieval Warm Period; PBO = Preboreal Oscillation; YD = Younger Dryas. A: Holocene

313 fluctuations of Tsidjiore Nouve Glacier $\left(46^{\circ} \mathrm{N}\right)$, represented as approximate glacier length

314 changes, estimated based on lateral moraine positions and historic records. White vertical dashed

315 lines indicate glacier length uncertainties. ${ }^{10} \mathrm{Be}$ age error bars $(1 \sigma)$ include the production rate

316 uncertainty. Note that moraine sequences are discontinuous records of glacier behavior, indicated

317 here by the dashed curves and the question marks. B: Two recession events of Tsidjiore Nouve

318 Glacier, evident from ${ }^{14} \mathrm{C}$-dated soils within the 'LIA' composite moraine (Röthlisberger, 1976). 
Publisher: GSA

Journal: GEOL: Geology

Article ID: G33169

319 C: Re-advance of Mont Miné Glacier (Valais) to its modern extent inferred from ${ }^{14} \mathrm{C}$-dated

320 proglacial fossil trees (Nicolussi and Schlüchter, 2012). D: Recession periods of six Swiss

321 glaciers deduced from ${ }^{14} \mathrm{C}$-dated proglacial wood and peat (Joerin et al., 2006). E: Behavior of

322 the Upper Grindelwald Glacier inferred from petrographic and stable isotope changes in

323 speleothems (Luetscher et al., 2011). F: $\delta^{18} \mathrm{O}$ records in sediment of two Swiss lakes at

324 Gerzensee and Leysin (Schwander et al., 2000). G: GISP2 $\delta^{18} \mathrm{O}$ record (Stuiver et al., 1995). H:

325 500-year smoothed record of Greenland surface temperature based on GISP2 borehole

326 measurements (Cuffey and Clow, 1997). I: Titanium concentrations in Cariaco Basin sediments

$327\left(10^{\circ} \mathrm{N}\right)$ as a proxy for precipitation changes (Haug et al., 2001).

$328{ }^{1}$ GSA Data Repository item 2012xxx, supporting data tables and figures, is available online at

329 www.geosociety.org/pubs/ft2012.htm, or on request from editing@geosociety.org or Documents

330 Secretary, GSA, P.O. Box 9140, Boulder, CO 80301, USA. 


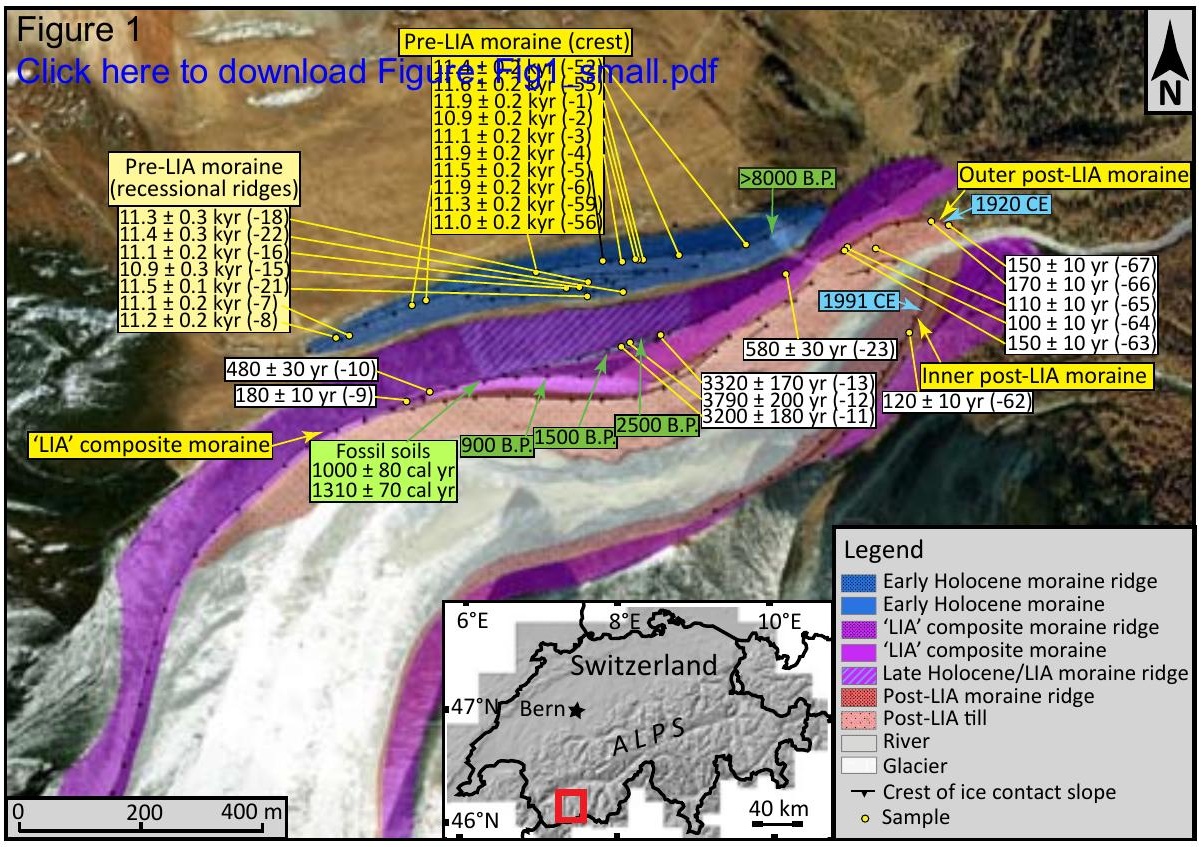


Recessional ridges $(n=7)$

Crest $(n=10)$

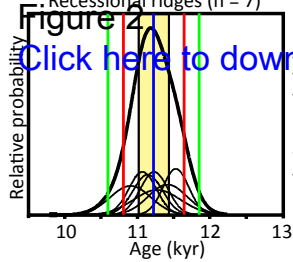

Ar. mean \pm st.dv.: $11,230 \pm 210$ yr Ar. mean \pm st.dv.: $11,440 \pm 380 \mathrm{yr}$ Weighted mean: $11,250 \pm 80 \mathrm{yr}$ Weighted mean: $11,440 \pm 60 \mathrm{yr}$ 
É \begin{tabular}{llllll} 
& 6 & 6 & 8 & 10 & 12 \\
\hline
\end{tabular} Êtisk here to download Figure: Fig3
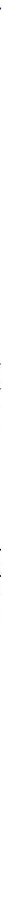


\title{
DATA REPOSITORY for:
}

\section{Holocene glacier culminations in the Western Alps and their hemispheric relevance}

Irene Schimmelpfennig, Joerg M. Schaefer, Naki Akçar, Susan Ivy-Ochs, Robert C. Finkel, Christian Schlüchter

\author{
Geology
}


Table DR1: Sample details, analytical data and surface exposure ages. Sample ${ }^{10} \mathrm{Be} /{ }^{9} \mathrm{Be}$ ratios, measured at the Center for Accelerator Mass Spectrometry of the Lawrence Livermore National Laboratory, were normalized to one of the indicated standards, KNSTD (until mid-2007; ${ }^{10} \mathrm{Be} /{ }^{9} \mathrm{Be}=3.15 \times 10^{-12}$ ) or KNSTD07 (after the year $2007 ;{ }^{10} \mathrm{Be} /{ }^{9} \mathrm{Be}=2.85 \times 10^{-12}$ ). Measurements normalized to KNSTD were corrected by a factor of 0.9048 during age calculation. The ages are calculated using the ${ }^{10} \mathrm{Be}$ production rate with a value of $3.85 \pm 0.19$ atoms $(\mathrm{g} \mathrm{yr})^{-1}$ (Balco et al. 2009, normalized to standard 07KNSTD) and the scaling method 'Lm' (time-dependent version of Lal, 1991) according to Balco et al. (2008). They are reported in calendar years before $2010 \mathrm{CE}$. $1 \sigma$ analytical uncertainties range between $1.5 \%$ and $3 \%$, except for samples younger than 500 years, which have uncertainties between $3 \%$ and $10 \%$.

\begin{tabular}{|c|c|c|c|c|c|c|c|c|c|c|c|c|c|c|}
\hline Sample name & $\begin{array}{l}\text { Latitude } \\
\left({ }^{\circ} \mathrm{N}\right)\end{array}$ & $\begin{array}{c}\text { Longitude } \\
\left({ }^{\circ} \mathrm{E}\right)\end{array}$ & $\begin{array}{c}\text { Elevation } \\
(\mathrm{m})\end{array}$ & $\begin{array}{c}\text { Thickness } \\
(\mathrm{cm})\end{array}$ & $\begin{array}{c}\text { Shielding } \\
\text { factor }\end{array}$ & $\begin{array}{l}\text { Qtz weight } \\
\text { (g) }\end{array}$ & $\begin{array}{c}\text { Carrier } \\
\left(\mathrm{mg}{ }^{9} \mathrm{Be}\right)\end{array}$ & $\begin{array}{c}\text { Carrier } \\
\left(\mathrm{mg}{ }^{9} \mathrm{Be}\right)\end{array}$ & $\begin{array}{c}{ }^{10} \mathrm{Be} /{ }^{\rho} \mathrm{Be} \\
\text { Standard } \\
\text { used }\end{array}$ & $\begin{array}{c}{ }^{10} \mathrm{Be} /{ }^{9} \mathrm{Be} \\
\times 10^{-14}\end{array}$ & $\begin{array}{c}{\left[^{[10} \mathrm{Be}\right]} \\
\left(\times 10^{3} \text { atoms } \mathrm{g}^{-1}\right)\end{array}$ & $\begin{array}{l}{ }^{10} \text { Be age } \\
\text { (years) }\end{array}$ & $\begin{array}{l}1 \sigma \text { Analyt. } \\
\text { error }\end{array}$ & $\begin{array}{l}1 \sigma \text { error } \\
\text { incl. prod. } \\
\text { rate error }\end{array}$ \\
\hline \multicolumn{15}{|c|}{ Pre-LIA MORAINE, BOULDERS ON CREST } \\
\hline ARO-4 & 46.01820 & 7.46480 & 2393 & 2.30 & 0.977 & 9.97 & 0.2040 & BE23706 & KNSTD & $25.15 \pm 0.36$ & $332.9 \pm 4.8$ & 11920 & 170 & 610 \\
\hline ARO-1 & 46.01824 & 7.46527 & 2387 & 4.36 & 0.977 & 16.55 & 0.2077 & BE23715 & KNSTD & $39.93 \pm 0.66$ & $325.1 \pm 5.4$ & 11880 & 200 & 620 \\
\hline ARO-6 & 46.01746 & 7.45986 & 2433 & 2.04 & 0.970 & 21.33 & 0.2060 & BE23716 & KNSTD & $54.0 \pm 1.0$ & $338.6 \pm 6.5$ & 11870 & 230 & 630 \\
\hline ARO-55 & 46.01838 & 7.46628 & 2371 & 1.89 & 0.977 & 12.04 & 0.1829 & BE31219 & 07KNSTD & $28.59 \pm 0.46$ & $289.9 \pm 4.7$ & 11610 & 190 & 600 \\
\hline ARO-5 & 46.01823 & 7.46434 & 2400 & 3.19 & 0.977 & 10.60 & 0.1991 & BE23707 & KNSTD & $26.45 \pm 0.44$ & $321.4 \pm 5.4$ & 11510 & 200 & 600 \\
\hline ARO-52 & 46.01858 & 7.46791 & 2345 & 1.91 & 0.978 & 17.54 & 0.1830 & BE31211 & 07KNSTD & $40.09 \pm 0.75$ & $279.0 \pm 5.2$ & 11350 & 210 & 600 \\
\hline ARO-59 & 46.01752 & 7.4602 & 2432 & 1.43 & 0.970 & 20.08 & 0.1836 & $\mathrm{BE} 31213$ & 07KNSTD & $48.04 \pm 0.89$ & $293.1 \pm 5.5$ & 11290 & 210 & 600 \\
\hline ARO-3 & 46.01823 & 7.46509 & 2389 & 2.50 & 0.977 & 10.06 & 0.2043 & BE23705 & KNSTD & $23.59 \pm 0.39$ & $309.9 \pm 5.2$ & 11140 & 190 & 580 \\
\hline ARO-56 & 46.01798 & 7.46267 & 2419 & 3.27 & 0.974 & 20.08 & 0.1840 & BE31212 & 07KNSTD & $45.83 \pm 0.85$ & $279.4 \pm 5.2$ & 10960 & 200 & 580 \\
\hline \multirow{2}{*}{\multicolumn{15}{|c|}{$\begin{array}{l}44.01824 \\
\text { ARO-2 } \\
\text { Pre-LIA MORAINE, BOULDERS ON RECESSIONAL RIDGES }\end{array}$}} \\
\hline & & & & & & & & & & & & & & \\
\hline ARO-21_2010Apr & 46.01762 & 7.46405 & 2393 & 2.13 & 0.943 & 5.57 & 0.1868 & BE29530 & 07KNSTD & $12.90 \pm 0.31$ & $285.6 \pm 7.0$ & 11650 & 290 & 640 \\
\hline ARO-21 ${ }^{-}$ & 46.01762 & 7.46405 & 2393 & 2.13 & 0.943 & 42.19 & 0.2053 & BE24922 & 07KNSTD & $89.6 \pm 1.8$ & $283.1 \pm 5.7$ & 11630 & 240 & $\begin{array}{l}840 \\
620\end{array}$ \\
\hline ARO-22 & 46.01762 & 7.46477 & 2381 & 2.62 & 0.954 & 5.34 & 0.1894 & BE28931 & 07KNSTD & $12.23 \pm 0.28$ & $279.2 \pm 6.6$ & 11420 & 270 & $\begin{array}{l}200 \\
630-1\end{array}$ \\
\hline ARO-21_re & 46.01762 & 7.46405 & 2393 & 2.13 & 0.943 & 20.15 & 0.1839 & BE31210 & 07KNSTD & $45.49 \pm 0.85$ & $277.0 \pm 5.2$ & 11330 & 210 & 600 \\
\hline ARO- 18 & 46.01788 & 7.46407 & 2399 & 1.91 & 0.966 & 4.53 & 0.1878 & BE28930 & 07KNSTD & $10.66 \pm 0.30$ & $283.8 \pm 8.2$ & 11280 & 330 & 650 \\
\hline ARO-8 & 46.01692 & 7.45804 & 2442 & 3.93 & 0.970 & 10.14 & 0.2051 & BE23708 & KNSTD & $24.33 \pm 0.41$ & $318.4 \pm 5.4$ & 11230 & 190 & 590 \\
\hline ARO-16 & 46.01777 & 7.46387 & 2399 & 1.61 & 0.954 & 5.14 & 0.1860 & BE28929 & 07KNSTD & $11.92 \pm 0.21$ & $277.7 \pm 5.1$ & 11150 & 200 & 590 \\
\hline ARO-7 & 46.01696 & 7.45834 & 2441 & 2.50 & 0.970 & 30.37 & 0.2048 & BE23717 & KNSTD & $72.5 \pm 1.2$ & $317.4 \pm 5.4$ & 11070 & 190 & 580 \\
\hline \multirow{2}{*}{\multicolumn{15}{|c|}{ 'LIA' COMPOSITE MORAINE, OUTMOST SUB-RIDGE }} \\
\hline & & & & & & & & & & & & & & \\
\hline ARO-12 & 46.01678 & 7.46504 & 2416 & 3.24 & 0.981 & 30.05 & 0.2017 & BE23712 & KNSTD & $24.49 \pm 0.41$ & $106.4 \pm 1.8$ & 3786 & 63 & 200 \\
\hline ARO-13 & 46.01694 & 7.46577 & 2398 & 2.26 & 0.974 & 30.32 & 0.2041 & BE23713 & KNSTD & $21.05 \pm 0.35$ & $91.6 \pm 1.5$ & 3320 & 55 & 170 \\
\hline \multirow{2}{*}{\multicolumn{15}{|c|}{$\begin{array}{l}\text { ARO-11 } \\
\text { 'LIA' COMPOSITE MORAINE, LIA SUB-RIDGE }\end{array}$}} \\
\hline & & & & & & & & & & & & & & \\
\hline ARO-23 & $\begin{array}{l}\text { Ne, LIA SUB-K } \\
46.01815\end{array}$ & 7.4691 & 2308 & 2.84 & 0.948 & 47.03 & 0.1535 & BE26085 & 07KNSTD & $6.34 \pm 0.14$ & $12.92 \pm 0.33$ & 577 & 15 & 32 \\
\hline $\begin{array}{l}\text { ARO-2 } \\
\text { ARO-10 }\end{array}$ & $\begin{array}{l}40.011515 \\
46.01598\end{array}$ & $\begin{array}{l}7.4091 \\
7.46050\end{array}$ & 2475 & $\begin{array}{l}2.84 \\
1.83\end{array}$ & $\begin{array}{l}0.948 \\
0.988\end{array}$ & 30.48 & 0.2039 & $\begin{array}{l}\text { DE20083 } \\
\text { BE23710 }\end{array}$ & KNSTD & $\begin{array}{l}0.03 \pm 0.14 \\
3.27 \pm 0.11\end{array}$ & $13.71 \pm 0.48$ & 475 & 16 & $\begin{array}{l}32 \\
28\end{array}$ \\
\hline \multirow{2}{*}{\multicolumn{15}{|c|}{$\begin{array}{l}\text { ARO-9 } \\
\text { OUTER Post-LIA RECESSIONAL MORAINE }\end{array}$}} \\
\hline & & & & & & & & & & & & & & \\
\hline ARO-66 & 46.01923 & 7.47315 & 2175 & 3.26 & 0.970 & 28.46 & 0.1558 & BE32368 & 07KNSTD & $0.998 \pm 0.058$ & $3.55 \pm 0.22$ & 170 & 10 & 13 \\
\hline ARO-63 & 46.0186 & 7.47057 & 2255 & 1.61 & 0.970 & 45.39 & 0.1553 & BE32367 & 07KNSTD & $1.470 \pm 0.064$ & $3.30 \pm 0.15$ & 148 & 7 & 10 \\
\hline ARO-67 & 46.01921 & 7.47357 & 2163 & 3.48 & 0.970 & 38.11 & 0.1563 & BE32369 & 07KNSTD & $1.145 \pm 0.067$ & $3.06 \pm 0.19$ & $\begin{array}{l}140 \\
148\end{array}$ & 9 & 12 \\
\hline ARO-65 & 46.01923 & 7.47315 & 2222 & 2.41 & 0.958 & 19.96 & 0.1846 & BE31215 & 07KNSTD & $0.453 \pm 0.029$ & $2.38 \pm 0.20$ & 111 & 9 & 11 \\
\hline \multirow{2}{*}{\multicolumn{15}{|c|}{ INNER Post-LIA RECESSIONAL MORAINE }} \\
\hline & & & & & & & & & & & & & & \\
\hline ARO-62 & 46.01702 & 7.47225 & 2254 & 2.93 & 0.960 & 49.40 & 0.1248 & $\mathrm{BE} 32366$ & 07KNSTD & $1.532 \pm 0.072$ & $2.53 \pm 0.12$ & 116 & 6 & 8 \\
\hline Blank name & $\begin{array}{l}\text { Processed } \\
\text { with }\end{array}$ & & & & & & $\begin{array}{c}\text { Carrier } \\
\left(\mathrm{mg}{ }^{9} \mathrm{Be}\right)\end{array}$ & $\begin{array}{c}\text { Carrier (mg } \\
\left.{ }^{9} \mathrm{Be}\right)\end{array}$ & $\begin{array}{l}{ }^{10} \mathrm{Be} /{ }^{\circ} \mathrm{Be} \\
\text { Standard } \\
\text { used }\end{array}$ & $\begin{array}{l}{ }^{10} \mathrm{Be} / /^{9} \mathrm{Be} \\
\times 10^{-14}\end{array}$ & $\begin{array}{l}\text { Total number of } \\
\text { atoms }{ }^{10} \mathrm{Be} \times 10^{3}\end{array}$ & & & \\
\hline Blank_1_07Feb23 & $\begin{array}{l}\text { AR0-2,-3,-- } \\
4,-5,-8\end{array}$ & & & & & & 0.2035 & BE23703 & KNSTD & $0.117 \pm 0.021$ & $15.4 \pm 2.7$ & & & \\
\hline Blank_2_07Feb23 & $\begin{array}{l}\text { ARO-9,-10,- } \\
11,-12,-13\end{array}$ & & & & & & 0.2051 & BE23714 & KNSTD & $0.118 \pm 0.019$ & $15.8 \pm 2.5$ & & & \\
\hline Blank _2 07 Jan19 & ARO-1,-6,-7 & & & & & & 0.2065 & BE23718 & KNSTD & $0.073 \pm 0.017$ & $9.8 \pm 2.3$ & & & \\
\hline Blank___2010Jan22 & ARO-15,-- & & & & & & 0.1895 & $\mathrm{BE} 28932$ & 07KNSTD & $0.116 \pm 0.021$ & $14.3 \pm 2.5$ & & & \\
\hline Blank 3 08Oct06 & $\begin{array}{l}16,-18,-22 \\
\text { ARO-23 }\end{array}$ & & & & & & 0.1534 & BE26086 & 07KNSTD & $0.252 \pm 0.053$ & $25.1 \pm 5.3$ & & & \\
\hline $\begin{array}{l}\text { Blank-3_-08cto } 06 \\
\text { Blank } 407 \text { Dec } 05\end{array}$ & $\begin{array}{l}\text { ARO-23 } \\
\text { ARO-21 }\end{array}$ & & & & & & $\begin{array}{l}0.1534 \\
0.2066\end{array}$ & $\begin{array}{l}\text { BE26086 } \\
\text { BE24923 }\end{array}$ & 07KNSTD & $\begin{array}{l}0.22 \pm 0.033 \\
0.747 \pm 0.013\end{array}$ & $\begin{array}{l}25.1 \pm 3.3 \\
10.0 \pm 1.8\end{array}$ & & & \\
\hline Blank_1_2010Apr20 & ARO-21 & & & & & & 0.1868 & BE29537 & 07KNSTD & $0.150 \pm 0.023$ & $18.7 \pm 2.8$ & & & \\
\hline Blank_2_2011Jan18 & $\begin{array}{l}\text { 2010Apr } \\
\text { ARO-21_re,- } \\
52,-56,-59,- \\
64,-65\end{array}$ & & & & & & 0.1837 & BE31218 & 07KNSTD & $0.069 \pm 0.015$ & $8.5 \pm 1.8$ & & & \\
\hline Blank_1_2011Jan18 & ARO-55 & & & & & & 0.1849 & BE31221 & 07KNSTD & $0.030 \pm 0.010$ & $3.7 \pm 1.2$ & & & \\
\hline Blank 12011 Oct4 & ARO-62 & & & & & & 0.1238 & BE32567 & 07KNSTD & $0.026 \pm 0.015$ & $2.1 \pm 1.3$ & & & \\
\hline Blank_2_20110ct4 & $\begin{array}{l}\text { ARO-63,- } \\
66,-67\end{array}$ & & & & & & 0.1546 & BE32376 & 07KNSTD & $0.027 \pm 0.009$ & $2.8 \pm 0.9$ & & & \\
\hline
\end{tabular}


Table DR2: Radiocarbon dates on fossil soils within superimposed deposits of the 'LIA' composite moraine (Figs. 1 and DR5a,b) and detrital logs found in basal till of the proglacial streambed at Tsidjiore Nouve Glacier (Fig. DR5c) and glacierclimatic significance (Röthlisberger, 1976, Röthlisberger and Schneebeli, 1979). All calibrated ages below are given as $2 \sigma$ intervals, referenced to the year $1950 \mathrm{CE}$ (=BP, before present). They are calibrated with OxCal 4.1 (Bronk Ramsey, 2009, 2011) relative to the IntCal09 calibration data set (Reimer et al., 2009).

\begin{tabular}{|c|c|c|c|}
\hline Dated material & Uncal. age $\left({ }^{14} \mathrm{C}-\mathrm{yr}\right)$ & Cal. age (yr BP) & Glacier-climatic significance \\
\hline $\begin{array}{l}\text { Upper fossil soil in } \\
\text { moraine }\end{array}$ & $1075 \pm 80$ & $1180-800$ & \multirow{2}{*}{$\begin{array}{l}\text { Timing of 'favorable' (warm) } \\
\text { climate, minimum age for } \\
\text { moraine deposition }\end{array}$} \\
\hline $\begin{array}{l}\text { Lower fossil soil in } \\
\text { moraine }\end{array}$ & $1380 \pm 85$ & $1510-1080$ & \\
\hline Fossil log & $2940 \pm 150$ & $3440-2770$ & \multirow{2}{*}{$\begin{array}{l}\text { Timing of glacier advance, } \\
\text { following a period of warmer } \\
\text { climate }\end{array}$} \\
\hline Fossil log & $8400 \pm 200$ & $10120-8780$ & \\
\hline
\end{tabular}

Table DR3: Statistics of the ${ }^{10} \mathrm{Be}$ ages from the crest and the recessional ridges of the pre-LIA moraine including different mean ages with respective uncertainties and the reduced chi-squares. For the 'weighted mean', both mean age and uncertainty were weighted by the inverse variances (e.g. Taylor, 1997). The relative high chi-square value is a result of the exceptionally small $1 \sigma$ analytical errors of the individual ages $(\sim 1.5 \%)$. Hence, for both crest and recessional ridges the boulder age distributions indicate that significant errors due to complex geological conditions (inheritance from prior exposure, erosion, or boulder instability) or snow cover are unlikely.

\begin{tabular}{lll}
\hline & ${ }^{10} \mathrm{~B}$ ages on crest $(\mathrm{n}=10)$ & ${ }^{10} \mathrm{Be}$ ages on recessional ridges $(\mathrm{n}=7)$ \\
\hline Arithmetic mean \pm standard deviation & $11,440 \pm 380$ years & $11,230 \pm 210$ years \\
- incl. production rate uncertainty & $11,440 \pm 680$ years & $11,230 \pm 590$ years \\
Weighted mean & $11,440 \pm 60$ years & $11,250 \pm 80$ years \\
Peak age & 11,470 years & 11,190 years \\
Median age \pm interquartile range & $11,430 \pm 730$ years & $11,230 \pm 290$ years \\
Reduced $\mathrm{X}^{2}$ & 3.9 & 0.9 \\
\hline
\end{tabular}




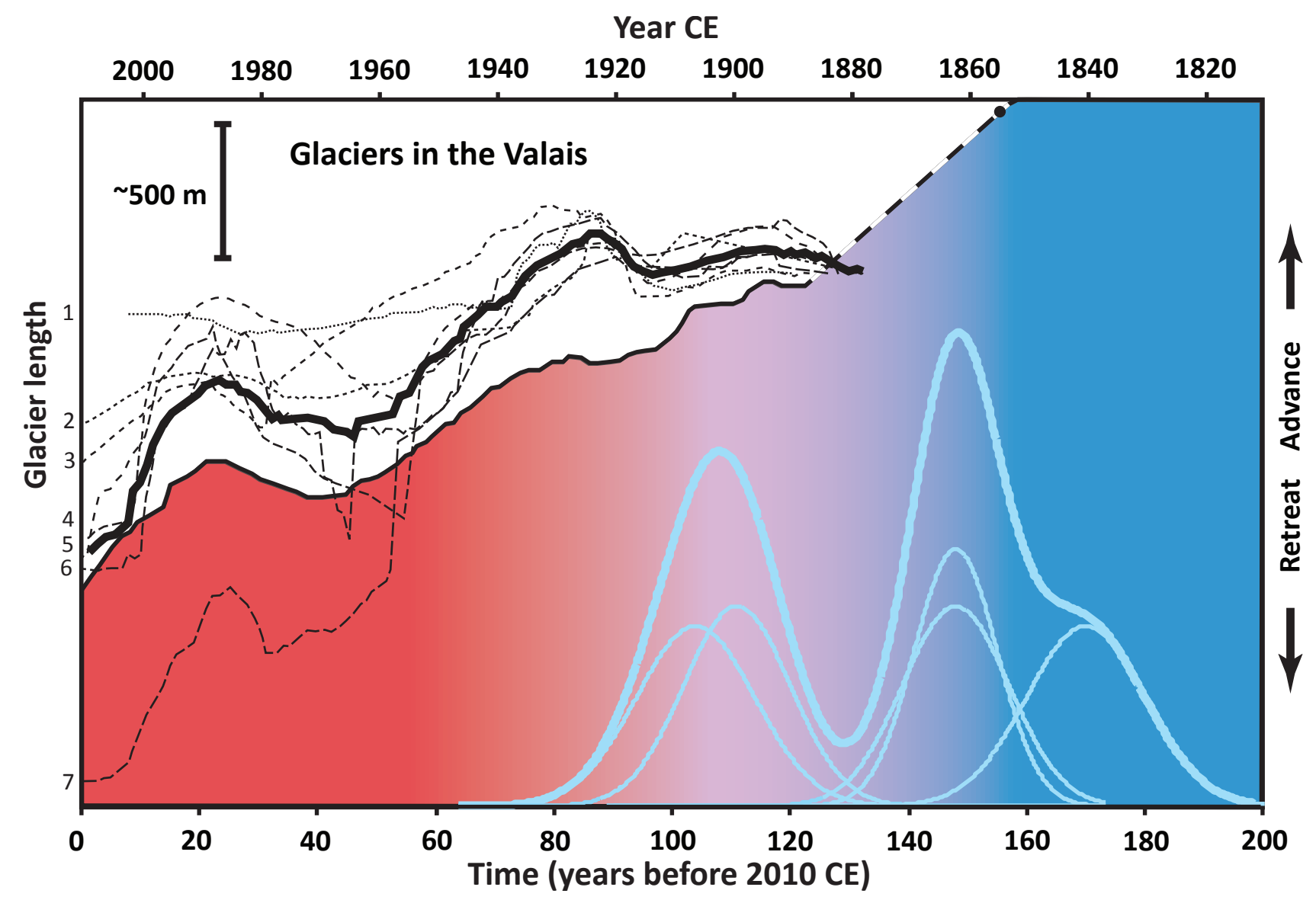

Fig. DR1: Post-LIA length measurements of several glaciers in the Valais, Switzerland. The red and dark blue graph shows length changes of Arolla Glacier (direct neighboring glacier of Tsidjiore Nouve; Glaciological reports, 1881-2009). The dashed thick line of this graph indicates lack of continuous measurements between the years 1856 and 1886 . Thin superposed lines are length measurements of seven other glaciers in the Valais starting around the year 1880, with the thick black line representing their average: 1 Fee Glacier, 2 Schwarzberg Glacier, 3 Lang Glacier, 4 Rossbode Glacier, 5 Trient Glacier, 6 Allalin Glacier, 7 Findelen Glacier. All glaciers show similar fluctuation patterns, i.e. during the general retreat from the LIA maximum a two-fold re-advance occurred between 1890 and $1930 \mathrm{CE}$, followed by another re-advance between $1970 \mathrm{CE}$ and $1990 \mathrm{CE}$. The thick light blue curve is the summed probability plot of the individual ${ }^{10} \mathrm{Be}$ ages (thin light blue curves) from the outer post-LIA moraine. 


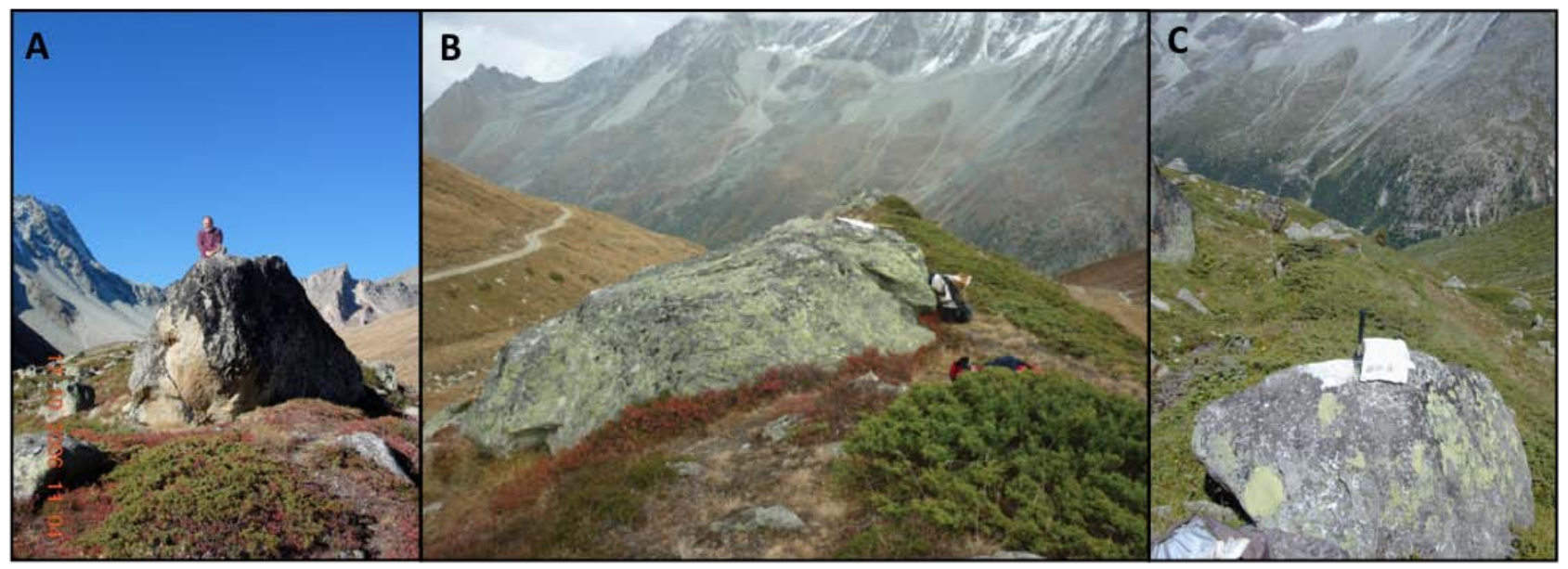

Fig. DR2: Examples of sampled boulders. A and B: ARO-1 (view west) and ARO-59 (view east), respectively, both embedded on the crest of the pre-LIA moraine. C: ARO-16, protruding from a recessional ridge of the pre-LIA moraine, view east.

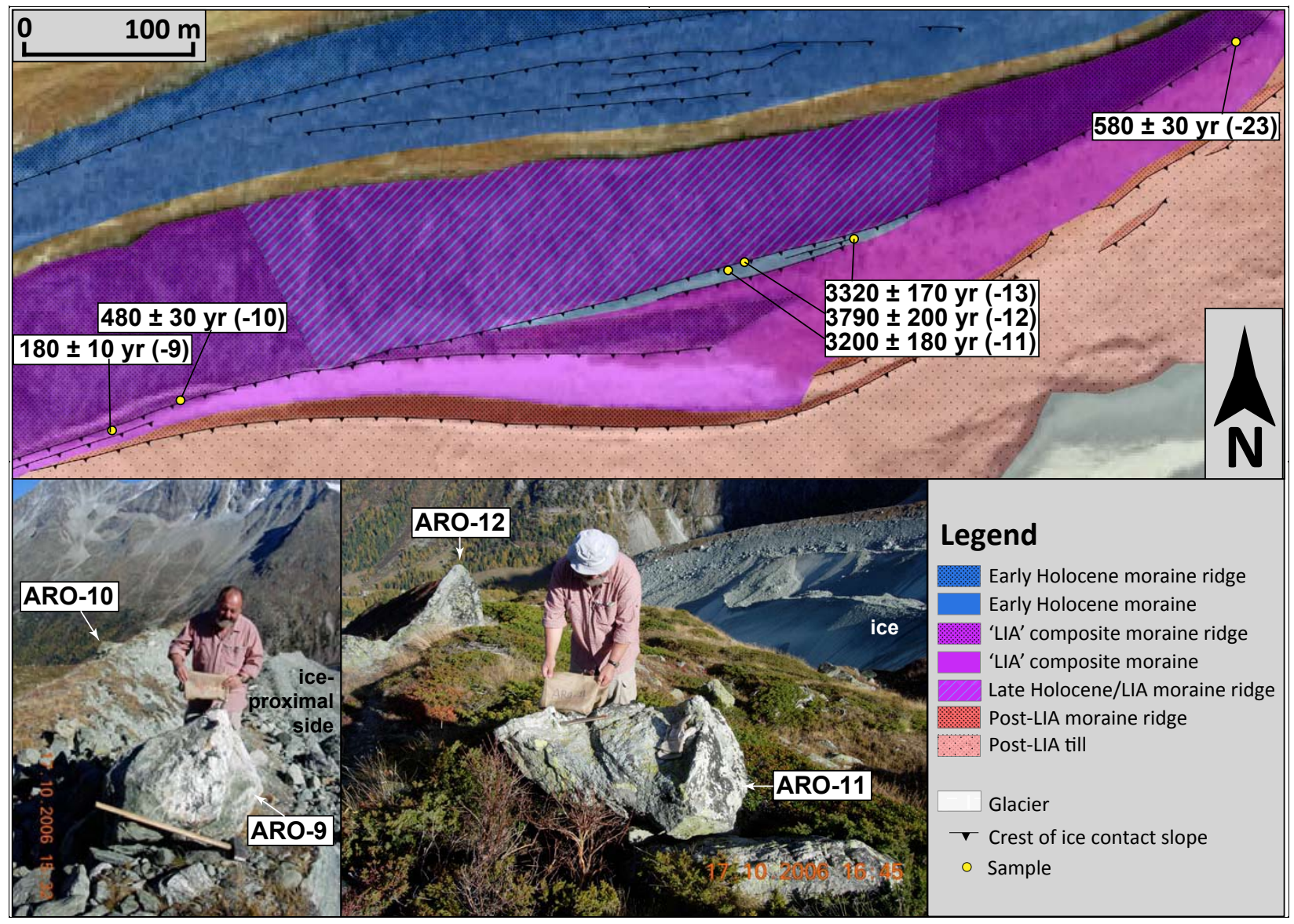

Fig. DR3: Positions of late Holocene and LIA boulders on the 'LIA' composite moraine. The upper panel displays the corresponding sample sites and ages in a zoom-in of the moraine map given in Fig. 1. The left photograph shows the position of boulder ARO-9, which is on a more ice-proximal and thus stratigraphically younger subsection of the composite moraine than boulder ARO-10, in agreement with the ${ }^{10}$ Be chronology. Similarly, the right picture shows that ARO-12 is in a slightly more ice-distal and therefore stratigraphically older position than ARO-11, again in agreement with the ${ }^{10} \mathrm{Be}$ ages. 

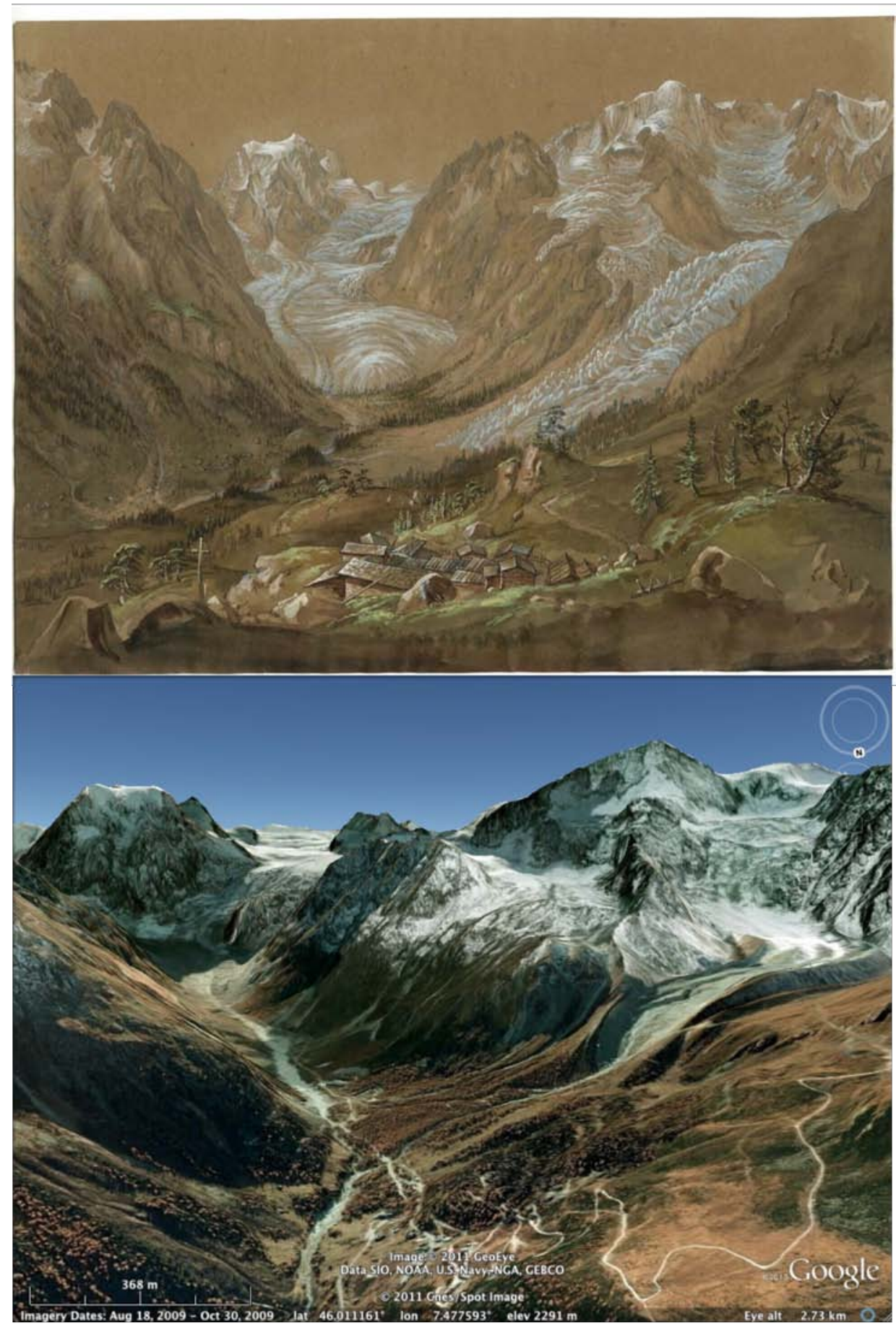

Fig. DR4: Upper panel: Drawing by Bühlmann from the year 1836 CE (Skizzenbücher Bd. 10, 256, Graphische Sammlung ETH, Zürich) showing the Tsidjiore Nouve Glacier on the right, the Arolla Glacier on the left and the village Arolla in the front. Glacier terminus positions are close to their Little Ice Age peak extent. Lower panel: Google Earth picture of approximately the same view in the year $2009 \mathrm{CE}$. 

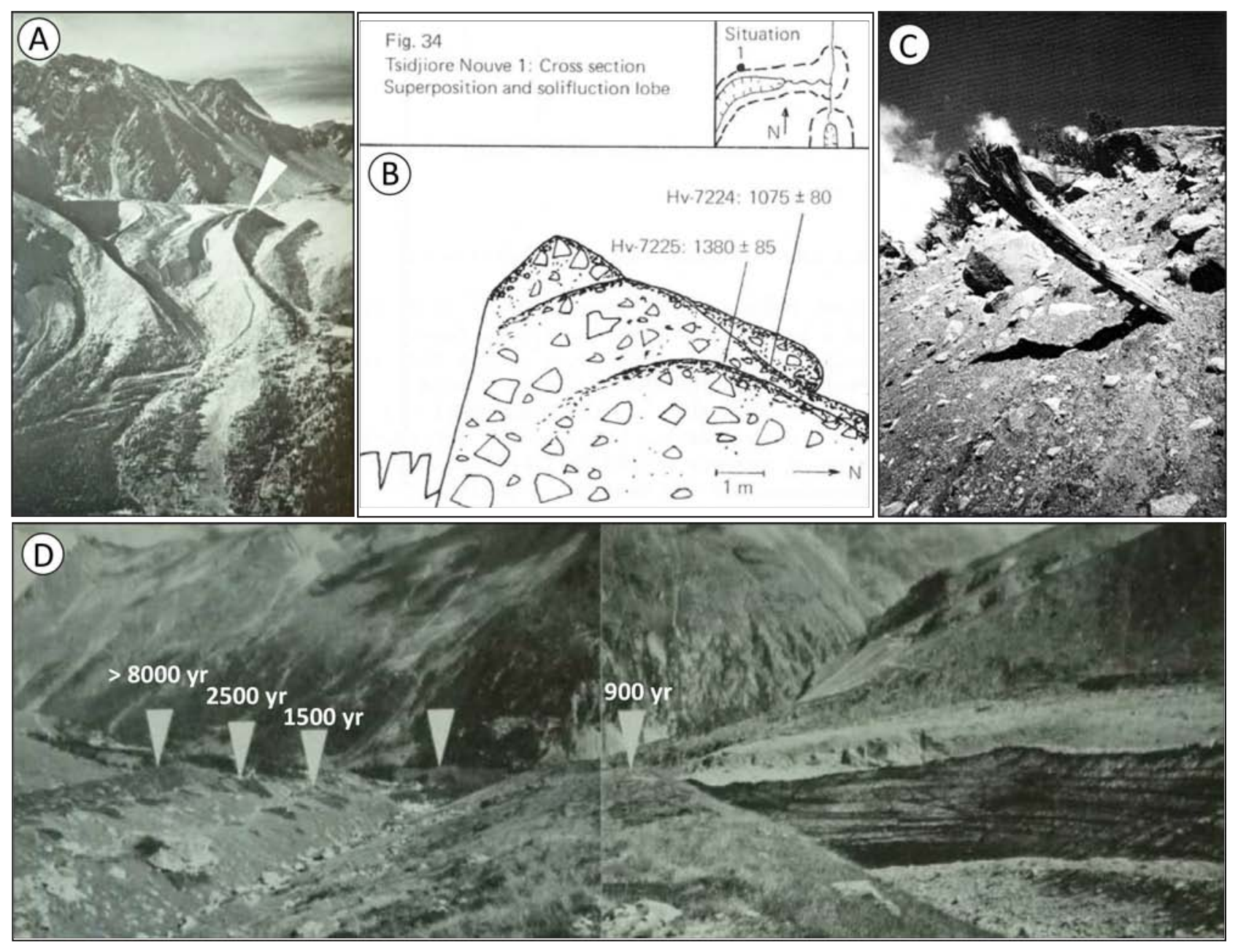

Fig. DR5: Figures from the earlier work on the Holocene moraine sequence at Tsidjiore Nouve Glacier (Röthlisberger, 1976; Röthlisberger and Schneebeli, 1979). A: Photograph of the glacier and the moraine sequence in the year 1972 with white arrow pointing to the location of the excavated fossil soils. B: Schematic illustration of the two fossil soils found in superimposed moraine deposits in the 'LIA' composite moraine and corresponding ${ }^{14} \mathrm{C}$ ages. According to the authors, the younger fossil soil was covered by solifluction during a cold period. C: Radiocarbon dated larch log embedded in basal till and washed out by the glacial stream (3440-2770 cal years BP). D: Left lateral moraine sequence with pilot age estimates, which are based on 4 radiocarbon dates at Tsidjiore Nouve Glacier (summary in Table DR2) in combination with radiocarbon dates from the nearby glaciers Findelen, Mont Miné, and Ferpècle (Röthlisberger, 1976; Röthlisberger and Schneebeli, 1979). The deposition ages of 2500,1500 and 900 years are presumably mostly inferred from ${ }^{14} \mathrm{C}$ ages at the three nearby glaciers. The white arrow in the back points to terminal moraine of the year $1817 \mathrm{CE}$.

\section{References:}

Balco, G., Stone, J., Lifton, N., and Dunai, T., 2008, A complete and easily accessible means of calculating surface exposure ages or erosion rates from 10Be and 26Al measurements, Quaternary Geochronology 3, p. 174-195.

Balco, G., Briner, J., Finkel, R. C., Rayburn, J. A., Ridge, J. C., and Schaefer, J. M., 2009, Regional beryllium-10 production rate calibration for late-glacial northeastern North America, Quaternary Geochronology 4, p. 93-107.

Bronk Ramsey, C., 2009, Bayesian analysis of radiocarbon dates, Radiocarbon, 51, p. 337-360. 
Bronk Ramsey, C., 2011. OxCal Program 4.1, http://c14.arch.ox.ac.uk/oxcalhelp/hlp_contents.html

Glaciological reports (1881-2009) "The Swiss Glaciers", Yearbooks of the Cryospheric Commission of the Swiss Academy of Sciences (SCNAT) published since 1964 by the Labratory of Hydraulics, Hydrology and Glaciology (VAW) of ETH Zürich. No 1-126, (http://glaciology.ethz.ch/swiss-glaciers/).

Lal, D., 1991, Cosmic ray labeling of erosion surfaces: in situ nuclide production rates and erosion models, Earth and Planetary Science Letters 104, p. 424-439.

Reimer, P.J., and 27 others, 2009, IntCa109 and Marine09 radiocarbon age calibration curves, 0-50,000 years cal BP, Radiocarbon 51, p. 1111-1150.

Röthlisberger, F., 1976, Gletscher- und Klimaschwankungen im Raum Zermatt, Ferpècle und Arolla, Die Alpen 52, p.59152.

Röthlisberger, F., and Schneebeli, W., 1979, Genesis of lateral moraine complexes, demonstrated by fossil soils and trunks: indicators of postglacial climatic fluctuations, in Schlüchter, C., ed., Moraines and Varves. A.A. Balkema, Rotterdam, p. 387-419.

Taylor J.R., 1997, An Introduction to Error Analysis. The Study of Uncertainties in Physical Measurements, University Science Books, Sausalito, 327 p. 